\title{
SLAVENHANDEL EN RECHTSBEDEELING OP CURAÇAO OP HET EINDE DER 17E EEUW
}

\author{
DOOR
}

\section{W. R. MENKMAN}

De notarieele archieven onzer groote koopsteden bevatten vele acten, zoowel in de Spaansche als in de Nederlandsche taal, welke van belang zijn voor de geschiedenis van onzen handel met Spanje na den vrede van Munster en met West-Indië.

De Rotterdamsche acten, alsmede het extract uit het register der resolutiën van de Staten van Holland en West Friesland, waarover in dit artikel zal worden gesproken, danken wij aan Mr. H. C. Hazewinkel, adjunct gemeente-archivaris van Rotterdam, die op de gelukkige gedachte kwam dat de inhoud dezer stukken voor de lezers van De West-Indische Gids interessant zou kunnen zijn; de Amsterdamsche notarieele acte zocht ik op in het gemeente-archief alhier.

Ik zal beginnen met iets mede te deelen uit het eerste der door Mr. Hazewinkel beschikbaar gestelde bescheiden, dat ons iets leert over den slavenhandel, waarin Curaçao een tijdlang een belangrijke rol heeft gespeeld en uit het laatste stuk uit den bundel, een van negen jaar later, dat nieuw licht werpt op de Curaçaosche rechtsbedeeling, heel op het einde der 17e eeuw.

De eerste acte is van 3 September 1686 (Notarieel archief 1473 no. 28); zij werd verleden ten overstaan van Gomaro (de acte is in het Spaansch) van Bortel (Klaeszoon), notaris te Rotterdam. Het N. Nederl. Biographisch Woordenboek geeft Gomarus of Gommer van Bortel (Bastiaansz.), beroemd Amsterdamsch chirurgijn (1660-1724); deze was een neef van onzen notaris.

Comparant was Josua van Belle, een Rotterdammer, die tusschen 1630 en 1636 geboren werd en in 1710 overleed. Hij vertoefde lang in Spanje en werd na zijn terugkomst van daar lid der Rotterdamsche vroedschap (1676), later burgemeester (17051706) en in 1678 bewindhebber der Oost-Indische Compagnie. 
Hij was Heer van Waddinxveen en had in Spanje schilderijen verzameld; zijn te Dublin aanwezige portret wordt toegeschreven aan Murillo (N. Ned. Biogr. Wbk. I, 283). Een aanzienlijk man dus (hij was ook nog vrijheer van St. Hubertsgerecht), die desniettemin betrokken was bij den slavenhandel, reeds destijds niet algemeen als een nobel bedrijf beschouwd, maar een waarop nog niet met zooveel minachting werd neergezien als een goede 100 jaar later. De zeeofficier Cornelius de Jong noemt dien handel een schande der menschheid, maar zijn reis naar de Caraibische Eilanden van 1780-1781 verscheen pas in 1807, het jaar der beroemde Engelsche parlementsacte.

Als getuige bij het passeeren der acte trad op Coenrado de Termeyer, die later op Curaçao is geweest voor het slavenasiento en die ook in verschillende andere acten genoemd zal worden. Mr. Hazewinkel teekende van C. Determeyer op, dat hij omstreeks 1660 te Osnabrück geboren was, in 1679 boekhouder was van Josua van Belle en in 1700 het burgerrecht van Rotterdam verkreeg. Determeyer's tweede vrouw was de zuster van den Lutherschen predikant Johannes Wilkens te Haarlem en hij zelf was na zijn Curaçaoschen tijd diaken der Luthersche gemeente te Rotterdam, in welke kwaliteit hij in 1695 zich in den kerkeraad nogal liet gelden ${ }^{1}$ ). Zijn op 20 December 1696 geboren zoon Johannes kan de Luthersche predikant zijn, die 9 Januari 1721 te Rotterdam werd ingezegend $\left.{ }^{2}\right)$. Mr. Hazewinkel vond nog een notarieele acte van 3 Januari 1686, waarbij kapitein Pieter Abrahamsz. aan Coenraat de Termeyer een obligatie overdroeg ,geteekent op Curassauw op den 2en Oct. 1683 bij „Balthasar Beck, coopman tot Curassauw” ten bedrage van 800 stukken van achten. Over Balt. Beck hierna meer.

Om terug te komen op Josua van Belle, de reden voor zijn compareeren voor notaris Van Bortel was dat hij voor een vierde geinteresseerd was in een vordering van 50.000 daalders van 50 stuivers (escudos de cincuenta placas cada uno) en hij verklaarde de Heeren Joseph Morales en Christoval Garcia de Segovia, beiden inwoners van Sevilla, te hebben gemachtigd het hem komende in te vorderen en te ontvangen van den Heer Balthazar Coymans, wanneer Pedro van Belle (broeder van Josua) geen remise mocht

1) J. C. Schultz Jacobi, Geschiedenis der Evangelisch Luthersche gemeente te Rotterdam, 177.

2) Mr. J. Loosjes, Naaml. Predikanten, Hoogleeraren en Proponenten der Luthersche kerk in Nederland. 
hebben gemaakt met de galjoenen welke verwacht werden onder den admiraal Gonzale Chaxon.

Wij zitten hiermede midden in den slavenhandel; de transactie waarom het gaat wordt iets duidelijker na lezing der acte, welke op 10 April 1685 verleden was voor den Amsterdamschen notaris Pieter de Wit en waarbij alle belanghebbenden bij de 50.000 daalders gezamenlijk de hooger genoemden twee heeren te Sevilla, alsmede Manuel Delgado, welke laatste echter inmiddels was overleden, tot hun gemachtigden aanstelden.

Van Balthazar Coymans teekent het N. Ned. Biogr. Wbk. aan dat hij wel een zoon zal geweest zijn van Isaac Coymans, die ook al reeds bij den slavenhandel, of in ieder geval bij den Afrikaanschen handel betrokken was geweest en een tegenstander der West-Indische Compagnie. Door de onthullingen, in 1662, van Hendrick Caerloff, gewezen commies en fiscaal der West-Indische Compagnie, werd o.a. ook Isaac Coymans gecompromitteerd, in verband met de Deensch-Africaansche Compagnie, evenals de De Geersche Sweedsche Afrikaansche Compagnie een camouflageonderneming, om het monopolie der West-Indische Compagnie te ontduiken ${ }^{1}$ ).

Evenals Josua van Belle was de Amsterdammer Balthazar Coymans een voornaam personage, Schepen der stad, Ridder, Heer van Streefkerke; ook hij echter had groote belangen bij den slavenhandel. B. Coymans was n.l. administrateur van het Spaansche asiento de negros en Pieter van Belle was administrateur-generaal in de West (en Indias).

De Koning genoot onder dit asiento $112 \frac{1}{2}$ patacas (pesos) per ton scheepsruimte (van de in den slavenhandel gebruikte vaartuigen), welk recht vooraf moest betaald worden. Z.M. had op een oogenblik een assignatie afgegeven voor 200.000 daalders en voor een vierde dier som (de 50.000 daalders der Rotterdamsche acte) was te Madrid een wissel getrokken, welke, op verzoek van Balthazar Coymans, door eenige personen in Nederland was betaald. Coymans zou hun daartegenover uitkeeren het een vierde gedeelte van 335.000 pesos (dus P 83.750.-), welke hij, of zijn firma, van de Koninklijke kassen in de West (en Indias) te goed had en welke Pieter van Belle verwacht werd over te zullen maken met de retourvloot. Wij leeren nog uit de Amsterdamsche acte, dat op zulk een vloot een „maestro de plata” meevoer,

$\left.{ }^{1}\right)$ Mr. N. de Roever, Twee concurrenten van de eerste West-Indische Compagnie. Oud Holland. VII, 1889. 
een schatmeester dus over het aan boord aanwezige gemunte en ongemunte edele metaal.

De laatste acte van den Rotterdamschen bundel werd verleden op 5 April 1695 voor den notaris Jean du Clou. De Heer Coenraat de Termeyer, nu koopman te Rotterdam, gaf, ten verzoeke van de voogden over de minderjarige kinderen en erfgenamen van wijlen Balthazar Beck, in leven koopman op Curaçao, een verklaring af aangaande de wijze waarop voor den Raad van genoemd eiland geprocedeerd werd.

In den loop van iets meer dan een halve eeuw komen in de geschiedenis van Curaçao vijf Becks voor als regenten en notabelen. Matthias Beck was vice-directeur van het eiland en dat in ieder geval reeds in het begin van 1656, dus toen onze drie Benedenwindsche eilanden onder Pieter Stuyvesant met Nieuw-Nederland één bestuursgebied vormden ${ }^{1}$ ). M. Beck was lidmaat der N.H. gemeente op Curaçao en tegelijk met hem was aldaar zijn broeder Wilhelmus, of Wilhelm; ook leefden in 1659 op Curaçao Leonora Beck en Anna Beck, huisvrouw van Ds. Adr. van Beaumont, terwijl Margaritha Beck, weduwe van wijlen Johan Schif, als getuige bij een doopplechtigheid aldaar door een andere koloniste werd vertegenwoordigd ${ }^{2}$ ).

Matthias werd zelfstandig directeur, toen in 1664 Nieuw-Nederland Engelsch was geworden en daarmede aan het bestuur van daaruit over de Benedenwindsche eilanden een einde was gekomen; hij stierf op Curaçao in 1668 en werd voorloopig door zijn reeds genoemden broeder W. Beck opgevolgd, die kort daarop nog eens met het interimaat belast werd, toen de in 1669 benoemde Lodevicus Boudewijn van Berlicum, kort na aankomst in de kolonie, was komen te overlijden ${ }^{3}$ ).

Balthazar Beck was in 1673, bij de Fransche „rodomontade”, vaandrig der burgerij en in 1679 was hij als kapitein-luitenant der burgerij getuige bij den doop van het eerste kind van directeur Jan Doncker ${ }^{3}$.

Van 1704 tot zijn vertrek in 1709 was Mr. Jacob Beck directeur, van 1709 tot zijn dood in 1710 zijn broeder Abraham Beck ${ }^{3}$ ).

1) Archief Albany, N. Y., notulen vergadering Raad op Curaçao 21 Februari 1656.

2) Prof. Dr. L. Knappert, Gedenkboek Nederland-Curaçao 16341934. den.

s) J. H. J. Hamelberg, De Nederlanders op de West-Indische eilan- 
Onze Balthazar Beck was factor van het Spaansche asiento op Curaçao en vooral in deze kwaliteit kreeg hij groot ongenoegen met den directeur Nikolaas van Liebergen (1679-1682) $\left.{ }^{1}\right)$. Deze laatste verbood de voor de Joden beleedigende Judasvertooning opWitten Donderdag aan boord van ter reede liggende Spaansche slavenschepen en Beck koos partij voor de Spanjaarden. In Nederland oefenden de invloedrijke Portugeesche Joden van Amsterdam pressie uit op de bewindhebbers der Compagnie, terwijl Van Belle voor Beck opkwam; deze laatste werd ten slotte als burgerkapitein afgezet.

Om nu terug te komen op de attestatie van Coenraad Determeyer, deze verklaart onder aanbod van eede en op grond van eigen ervaring, opgedaan tijdens zijn verblijf op Curaçao (van Maart 1687 tot omstreeks April 1689), dat aldaar door den Raad geen vaste zittingsdagen gehouden werden, maar deze door den directeur willekeurig bijeengeroepen werd; dat de leden ook niet altijd dezelfde waren, ten eerste omdat de schippers der ter reede liggende Compagniesschepen zitting en stem hadden, ten tweede omdat de directeur soms nieuwe leden aan den Raad toevoegde, of vaste leden niet opriep. De genoemde schippers en de toegevoegde leden legden geen eed af. Schriftelijke dagvaarding was onbekend, schriftelijke pleidooien werden niet gehouden, ieder moest zijn eigen zaak bepleiten, want er was geen practizijn of notaris aanwezig, er bestond geen rol en er bestonden geen notulen; na afloop van een geding was van den secretaris niets anders te verkrijgen dan de bloote uitspraak.

Deze mededeelingen zijn interessant, omdat de instructie van 1764 voor den directeur Jean Isai Claris Rodier de la Brugière (1762-1781) althans voorschreef dat de Raad, ten gerieve van rechtzoekenden, alle veertien dagen zou vergaderen ${ }^{2}$ ) en deze instructie in hoofdzaak overeenstemde met de in 1679 voor Van Liebergen gearresteerde ${ }^{3}$ ).

De 17e eeuwsche rechtsbedeeling op Curaçao laboreerde allicht evenzeer aan het niet nakomen van de gegeven voorschriften, als aan het gebrekkige dier reglementen en de directeur, tevens president van den Raad, was heer en meester; getuige de uitlating van Stuyvesant, die eens in kernachtige bewoordingen uitsprak

$\left.{ }^{1}\right)$ J.H. J. Hamelberg. De Nederlanders op de West-Indische eilanden.

2) Hamelberg, Documenten, 190.

3) Mr. R. Bylsma, Verslagen omtrent 's lands oude archieven, XVIII, dl. I, 618 . 
wat hij in zijn tijd - d.w.z. toen hij nog directeur op Curaçao was - wel gedaan zou hebben met iemand die het zou hebben gewaagd van een sentensie van zijn Raad te appelleeren ${ }^{1}$ ).

De overige acten en bescheiden geven ons inzicht in de oneenigheden hier te lande en op Curaçao, welke uit de verhoudingen, door den slavenhandel geschapen, voortvloeiden, in dien handel zelf en in het wezen van het asiento.

Uit het extract der resoluties van de Staten van Holland van 21 April 1689 (blz. 220) blijkt dat de gemachtigden in Nederland van Balthazar Beck en van Coenraad Determeyer, beiden op Curaçao, bij de Staten Generaal gerequestreerd hadden, om te verzoeken dat de beide laatstgenoemden eindelijk ,mochten wesen verlost „van alle de ongehoorde vexatien ende quade conduite haer „aengedaan door den directeur Willem Kerckring”. Behalve Beck en Determeyer zou ook een zekere "cappellaen” gelaedeerd zijn en hun klachten zouden niet alleen tegen Kerckring, maar ook tegen de West--Indische Compagnie gericht zijn; klagers zouden voor een door H.H.M. aan te wijzen hof van justitie willen procedeeren. Er werd besloten dat de gecommitteerden tot de saecken van de Justitie een onderzoek zouden instellen en den Staten zouden adviseeren. Waarover de klachten liepen blijkt niet; hierover echter later meer. Kerckring was, evenals zijn voorganger Van Liebergen, een oud-bewindhebber der Compagnie.

Gemachtigde van Beck was Philippe van Hulten, terwijl voor Determeyer optrad Christiaen Meschman; beide gemachtigden waren kooplieden te Amsterdam.

Van Hulten zijn wij ook reeds tegengekomen in de Amsterdamsche notarieele acte van 10 April 1685; hij had in de transactie der 50.000 daalders voor rekening van Balthazar Beck voor een achtste deelgenomen. Verder kennen wij Van Hulten ook nog als gemachtigde van Van Aerssen van Sommelsdijk, den gouverneur van Suriname ${ }^{2}$ ).

Van Hulten was Katholiek, P. A. Euwens O.P. noemt Van Aerssen ,een zoo orthodox-gereformeerd gouverneur" ${ }^{3}$ ) en de Becks behoorden ook tot „de dominante kerk”. Protestantsche overheidspersonen en kooplieden echter hadden er blijkbaar geen bezwaar tegen zaken te doen met Roomschen en Joden; dit was zoowel in het moederland als in de koloniën de toestand.

1) Hamelberg, Documenten, 54.

2) J. Wolbers, Geschiedenis van Suriname.

s) Historisch Tijdschrift, 1930, bldz. 320. 
In de acte voor notaris G. van Bortel $\mathrm{Kzn}$. te Rotterdam, den 28 Sept. 1689 verleden (not. arch. 1475 no. 61) wordt directeur Kerckring er van beschuldigd aan de factorij van het asiento op 19 Maart 1688 een getal van 1075 slaven gewelddadig te hebben ontnomen, om het meerendeel te verschepen met de St. Jago de Victoria „nae de West Indiën” en in een andere acte, voor denzelfden notaris, van 11 November 1693 (not. arch. 1479 no. 169) wordt geconstateerd dat de directeur in 1688 alle effecten van het asiento aan B. Beck en C. Determeyer - de factors ter plaatsezou hebben ,ontweldigt” (hierover later meer).

Van de onderlinge verhouding der bij den slavenhandel betrokken financiers geeft de acte voor notaris Van Bortel van 31 Januari 1688 (not. arch. 1474 no. 3) een staaltje. Pieter van Belle, geboren te Rotterdam, maar burger of inwoner (vecino) van Cadix en 2 Januari 1688 te Amsterdam aangekomen, benoemde daarbij iemand te Madrid tot zijn gemachtigde, om te verschijnen voor den Koning, alsmede voor diens Indischen raad (el Real Consejo de Indias) en uiteen te zetten waarom Van Belle zich uit Madrid verwijderd had.

P. van Belle was compagnon van den nu overleden Balthazar Coymans; ook een latere acte voor notaris Van Bortel, die van 9 Maart 1689 (not. arch. 1475 no. 18) spreekt van het huis en van de societeit van P. van Belle en B. Coymans te Cadix.

Van Belle dan is alleen naar Holland gegaan om de broeders en zusters van Coymans te bezoeken (zij zijn volgens testamentaire beschikking erfgenamen van den overledene) en hun te vragen of zij de erfenis wenschen te aanvaarden. Francisco Schonenberg, gezant van den Prins van Oranje te Madrid, had geen volmacht om zich daarover uit te spreken.

De erfgenamen hebben geen besluit kunnen nemen en Van Belle zal nu verschillende bescheiden moeten laten opmaken, waarna hij direct naar Spanje terug denkt te keeren, om zich aan Koning en Raad te vertoonen. Intusschen echter vertrouwt comparant den Heer Schonenberg niet, hoewel hij met diens instemming en op zijn instigatie uit Spanje vertrokken is. Schonenberg had hem, toen hij aan het Hof was, gezegd dat hij gerust de reis kon ondernemen en de administratie aan Juan Carcau overlaten; te Amsterdam aangekomen echter bleek hem dat Schonenberg op 20 November 1687, d.i. enkele dagen na Van Belle's vertrek, aan Jan Coymans en Manuel de Belmonte had geschreven, dat Van Belle was heengegaan omdat hij zich niet veilig voelde aan het Hof. Ook aan de Heeren van den Indischen Raad had Scho- 
nenberg onware mededeelingen gedaan aangaande Van Belle.

Het is duidelijk dat er vrees voor bestaat dat de Koning in Van Belle's afwezigheid zal beïnvloed worden om iemand anders met de door wijlen Coymans behartigde slavenzaken te belasten; het zijn deze zaken welke Juan Cacau te Cadix ad interim moet waarnemen.

Op 3 Februari verscheen P. van Belle nogmaals voor notaris Van Bortel (not. arch. 1474 no. 9), om de instructies voor zijn gemachtigde te Madrid aan te vullen en uit te breiden. Deze gemachtigde moest bij Koning en Raad de lasterpraatjes van Schonenberg (gemachtigde der erfgenamen en belanghebbenden bij den boedel van Coymans) ontzenuwen, betreffende de z.g. vlucht van Van Belle uit Madrid.

Jan Coymans, in 1688 oud-schepen en raad van Amsterdam, kwam ook voor in de acte voor notaris De Wit te Amsterdam van 10 April 1685 , als voor $3 / 8(2 / 8$ voor hem zelf en $1 / 8$ voor een ander) deelnemende in de 50.000 daaldertransactie, waarbij ook Manuel de Belmonte betrokken was, voor 5000 daalders, voor zich zelf en voor François Schonenberg te zamen.

De Heer van Schoonenberg (vertaling van De Belmonte) was van Joodsche afkomst en Manuel zal wel een naaste bloedverwant van hem geweest zijn. Eerstgenoemde vertegenwoordigde in 1685 als buitengewoon gezant den Koning van Groot-Brittanje (den schoonvader van onzen Stadhouder) en als chargé d'affaires de Republiek der Vereenigde Nederlanden bij Su Majestad Católica te Madrid, Carlos II ${ }^{1}$ ). In 1694 bewees hij, nog steeds te Madrid, aan onze Regeering belangrijke diensten en in 1704 was hij onze gezant in Portugal ${ }^{2}$ ).

Pieter van Belle passeerde op 2 Februari 1688 nog een tweede acte voor notaris Van Bortel (not. arch. 1474, no. 8), een waarbij hij, op het punt van naar Spanje terug te keeren, zijn broeder Josua tot zijn algemeen gevolgmachtigde benoemde. Josua moest vooral zijn invloed aanwenden dat de West-Indische Compagnie zich in zake den negerhandel niet met Manuel de Belmonte of met Joan (Jan) Coymans inliet en hij mocht, wanneer hij dat wenschelijk achtte, de opdracht annuleeren welke dezen beiden Heeren door Juan Carcau gegeven was.

Nog twee machtigingen teekende P. van B. op 2 Februari 1688, beide ten overstaan van notaris Van Bortel, de eene (not. arch.

$\left.{ }^{1}\right)$ Wagenaar, Vaderlandsche Historie, XVI, 299.

2) J. C. de Jonge, Geschiedenis van het Nederl. Zeewezen, III, 428, $429,672$. 
1474 no. 5) ten behoeve van zijn broeder Josua, de andere (not. arch. 1474, no. 6) ten behoeve van John Gill te Londen. Josua zou mogen contracteeren met Benjamin Raule, voor de levering van slaven naar St. Thomas, Gill contracten af mogen sluiten met de Royal African Comp., of met particulieren, voor dergelijke leveringen naar Jamaica, of andere eilanden in America.

Raule, van Zuidnederlandsche afkomst, was omstreeks 1628 te Vlissingen geboren en overleed in 1678 te Hamburg; hij had in 1675 Brandenburgsche kaperbrieven verkregen tegen Zweden, maar al bij voorbaat zijn schepen zonder commissies laten ageeren, wat door de Staten-Generaal als neutraliteitsschennis hoog was opgenomen moeten worden en Raule had zwaar moeten boeten $\left.{ }^{1}\right)$. De Keurvorst echter maakte hem Oberdirector in Seesachen en Raule bevorderde in deze hoedanigheid de oprichting der Brandenburg-Afrikaansche Compagnie en de vestiging eener Brandenburgsche factorij op het Deensche St. Thomas ${ }^{2}$ ).

De Royal African Comp. in Engeland was opgericht in 1672; zij was houdster van het monopolie voor den aanvoer van slaven op de Britsche Westindische eilanden van 1680 tot 1688 , waarna deze handel vrij gegeven werd voor alle Britsche onderdanen.

Wat nu betreft den slavenhandel van Nederlandsche ondernemers, deze had, zooals uit de tot dusver behandelde bescheiden blijkt, gedeeltelijk wel en gedeeltelijk niet met het Spaansche asiento te maken; de zooeven genoemde leveringen voor Deensche en Britsche eilanden stonden natuurlijk daarbuiten.

Van 1662 tot 1671 waren de asentistas Domingo Fullo en Ambrosio Lomelin ${ }^{3}$ ) en het was met deze dat de West-Indische Compagnie een leveringscontract afsloot, zooals zij ook later gedaan heeft met volgende houders van het asiento ${ }^{4}$ ). Zoowel de eerste als de tweede W.I. Comp. hadden monopolie voor den aanvoer van slaven in de Nederlandsche Westindische vestigingen; de tweede stelde de door haar op Curaçao aangevoerde slaven voor een ieder te koop, met recht die uit te voeren waarheen men wilde.

1) Nieuw Nederl. Biogr. Woordenboek.

2) W. Westergaard, The Danish West Indies. Zie over Raule ook Rotterdamsch Jaarboekje 1932, blz. 32 e.v. (Een Rotterdamsche Tontine, door Mr. H. C. Hazewinkel, waarin ook nog enkele bijzonderheden aangaande C. Determeyer, de Van Belles en de Coymansen).

s) Enciclopedia universal ilustrada Europeo Americana.

•) Hamelberg, Nederl. o. d. W.-I. eilanden. 
Buiten de Nederlandsche gebieden was er echter een nog veel belangrijker markt, in de eerste plaats de Spaansche koloniën in Zuid- en Centraal-Amerika, Mexico en de Spaansche Antillen, die slechts voorzien mochten worden door de houders van het door den Koning verleende asiento, die dan op hun beurt weder contracteerden voor de levering der waar en van de schepen om die te vervoeren. De slaven kwamen uit verschillende gebieden ter Westkust van Afrika, waar onderscheiden Europeesche mogendheden vestigingen hadden, o.a. Nederland (El Mina aan de kust van Guiné).

Volgens de Enciclopedia universal ilustrada Europeo Americana kwam het asiento in 1682 aan Juan Borozzo del Pago en Nicolás Ponio de Cádiz, maar volgens een nog niet besproken Rotterdamsche acte van 9 Juli 1691 (P. van Belle voor notaris G. van Bortel, not. arch. 1477 no. 67) moet het reeds in Maart 1680 in handen van de beide genoemden (hier geheeten Juan Barosso y Posso en Nicolas Porcio) geweest zijn. P. van Belle en C. Determeyer verklaarden op 11 November 1693 (not. arch. 1479, no. 169, zie vroeger) dat Barosso y P. eerst houder was geweest en dat na zijn dood Porcio, zijn schoonzoon, hem was opgevolgd; deze laatste had zich met een deel der effecten van het asiento uit de voeten gemaakt, was van Panamá over Jamaica naar Spanje gevlucht en had zich daar in een klooster schuil gehouden.

Er schijnt nu een nogal ingewikkelde verhouding te zijn ontstaan, immers op 11 Nov. 1693 werd verklaard dat de Koning de „administratie” van het onder de „directie” van B. y P. \& P. zeer vervallen asiento aan Porcio ontnomen had en deze gegeven had aan Balthazar Coymans, volgens contract van 23 Februari 1685, zelfs met uitsluiting van Porcio. Was nu Coymans de houder van het asiento geworden? Het is wel eigenaardig dat op 3 September 1686 (not. arch. 1473, no. 28) van Coymans gesproken wordt als van den administrateur van het met B. y P. \& P. gesloten asiento; P. van Belle heette toen ,administrador general en In„dias", doch volgens een andere acte (not. arch. 1475, no. 61) was Coymans administrateur-generaal en Van Belle „factor„generaal”, wat waarschijnlijker is. Dat beide Nederlanders compagnons waren weten wij reeds; hun vestiging te Cadix heette (not. arch. 1474, no. 8) een ,societeyts comptoir”.

Coymans is vóór 15 November 1687 overleden (not. arch. 1474, no. 3) en wel te Cadix (not. arch. 1475, no. 18); zijn compagnon Van Belle verwachtte nu blijkbaar dat de generale administratie 
van het asiento aan hem toevallen zou. Op 31 Januari 1688 (not. arch. 1474, no. 3) noemt hij zich "sucessor destinado", op 3 Februari d.a.v. zelfs „sucessor nombrado" van den overleden administrateur-generaal (not. arch. 1474, no. 9). Nauwelijks in Nederland aangekomen, om met de erven Coymans te confereeren, ontdekte Van Belle dat er in Madrid tegen hem geintrigeerd werd en dat de Koning wel eens iemand anders kon aanstellen, onder pretext dat er geen orde op de zaken te Cadix gesteld was, hoewel met Zr. Ms. goedvinden Juan Carcau de loopende zaken zou behandelen (not. arch. 1474, no. 3). Carcau heette op 2 Februari 1688 de "pro interim directeur generaal" (not. arch. 1474, no. 8) en werd op 18 Februari 1688 te Madrid genoemd ,dewelke tegenwoordig de administratie bedient, die aen „Don Balthasar gegeven was". In een nog te behandelen acte voor notaris Van Bortel van 7 Juni 1689 (not. arch. 1475 no. 37) zullen wij Carcau „administrador del asiento de negros” genoemd vinden.

Van Belle intusschen baseerde zijn recht op de opvolging in de door Coymans bekleede functie zelfs op een testamentaire beschikking van dezen laatste, welke wilsbeschikking door den Koning goedgekeurd zou zijn (not. arch. 1475, no. 61). De acte voor notaris Van Bortel van 11 Juli 1689 (not. arch. 1475, no. 43), waarover later meer, doet vermoeden dat die goedkeuring vervat zou zijn in een Koninklijke cédula van 21 November 1686.

De Koning echter deed heel iets anders dan P. van Belle benoemen; Z.M. vaardigde op 18 Februari 1688 een ,cédula" uit, waarin werd gelast dat beslag zou worden gelegd, onder Carcau, op alle boeken, papieren, gelden, goederen en andere effecten van de door Coymans en Van Belle gevormde societeit te Cadix, een order welke op 4 Maart en volgende dagen werd uitgevoerd.

De vertaling der cédula en het verslag der inventarisatie zijn vastgelegd in de verklaring van Josua van Ouderkerk, die bij het geval tegenwoordig was geweest (not. arch. 1475, no. 18). Merkwaardig is dat in de vertaling van 's Koning's cédula ook al weder gesproken wordt van ,het asiento gemaekt met $\mathrm{D}^{\mathrm{n}}$ Nicolaes „Porcio y $\mathrm{D}^{\mathrm{n}}$ Juan Barosso ende naderhant voor de generale "administratie gegeven aen $\mathrm{D}^{\mathrm{n}}$ Balthasar Coymans", zoodat Coymans blijkbaar niet als een regelmatig asentista werd beschouwd.

De Koning had het beslag en de inventarisatie gelast, niet alleen uit hoofde der belangen welke de schatkist bij het asiento had, maar ook met het oog op geschillen tusschen belangheb- 
benden, aangezien zoovele instanties bij de zaken van het asiento betrokken waren. De Koninklijke cédula belastte met de uitvoering van beslag en inventarisatie een lid van den raad van financien van Z.M., iemand die echter tevens een functie bekleedde bij de Casa de contratación te Sevilla. Laatstgenoemd lichaam mocht zich echter volstrekt niet met het geval bemoeien, terwijl ook aan verschillende justitieele instanties verboden werd te intervenieeren; de Koning verwachtte van deze zijden alleen hulp en medewerking.

Het is niet duidelijk waarom Josua van Belle en C. Determeyer het op 11 November 1693 (not. arch. 1479, no. 169) lieten voorkomen alsof Pieter van Belle het indertijd niet raadzaam had geacht de administratie te aanvaarden. Ook op Curaçao had een beslag plaats gehad (zie vroeger) en dit zou het gevolg zijn geweest der omstandigheid dat door de ontzetting van Porcio, den dood van Coymans en de onwilligheid van P. van Belle om de administratie over te nemen, deze laatste geheel was komen te vervallen.

Een tot dusver nog niet in dit artikel genoemde acte intusschen werpt een eenigszins ander licht op de sequestratie op Curaçao. Ten verzoeke van zekeren Antonio Maldonado, die vroeger eenige slaventransporten van Curaçao naar Maracaibo en Caracas had overgebracht en nu te Cadix gevangen zat, legde Coenraad Determeyer ten overstaan van notaris Van Bortel in Augustus 1691 een verklaring af (not. arch. 1477 no. 80). Waarom Maldonado gevangen zat en waarom hij Determeyer's verklaring noodig had, is mij niet duidelijk kunnen worden, maar van belang is dat volgens comparant de directeur Kerckring gehandeld zou hebben ingevolge een geheime dispositie van de ons bekende Manuel de Belmonte en Jan Coymans, twee der Amsterdamsche gemachtigden van den administrateur-generaal a.i. Juan Carcau en niettegenstaande het protest van Josua van Belle, den derden gemachtigde van Carcau.

Uit de acte van 7 Juni 1689 voor notaris Van Bortel (not. arch. 1475 no. 38) lezen wij dat Kerckring door De Belmonte en Joan Coymans, als gemachtigden in Nederland der generale administratie in Spanje, tot factor benoemd was en op 9 October 1691 (not. arch. 1477, no. 104) verklaarde Josua van Belle dat Carcau zich herhaaldelijk bij hem schriftelijk beklaagt had, dat de beide andere gemachtigden particuliere orders hadden gegeven.

Het is dus duidelijk, dat van de driemanschap welke in Nederland zich met het asiento bezighield, alleen Josua van Belle er- 
voor werkte dat zijn broeder Pieter in de algemeene administratie zou opvolgen en dat de twee anderen dat trachtten te beletten. De meerderheid had blijkbaar namens Carcau opdracht gegeven dat op Curaçao alles wat tot het asiento behoorde uit handen van Beck en Determeyer zou worden overgenomen, omdat de nieuwe administratie zich niet van hen wenschte te bedienen. W. Kerckring, optredend als de nieuwe factor en van zijn macht als directeur van het eiland gebruik makend om den overdracht der zaken te forceeren, was wel een merkwaardige figuur.

Voorwaar, de slavennegotie was een niet veel minder avontuurlijk bedrijf dan de kaapvaart, schiep, evenals deze laatste, de ingewikkeldste situaties en leidde tot allerlei geraffineerde intrigues.

Niet Pieter van Belle is Balthazar Coymans opgevolgd, maar blijkbaar Juan Carcau. Eerstgenoemde heet op 9 Juli 1691 ,ge„wesen administrateur en factoor generaal van 't asiento der ",negros en derselver introductie in de Koninkrijken in Indien" (not. arch. 1477, no. 67).

Wel waren er nog geldzaken te vereffenen, ook wegens het overlijden van Balthazar Beck, welke laatste, de kapitein der burgerij op Curaçao, aldaar eerst factor geweest was van het asiento onder Barosso en Porcio, later van de nieuwe administratie onder Coymans, toen P. van Belle de administrateur in West Indië was. Op 9 Juli 1691 (not. arch. 1477, no. 67) wordt nog een verklaring afgelegd ten verzoeke van Beck en op 11 November 1693 (not. arch. 1479, no. 169) wordt van wijlen Balthazar Beck gesproken, dus deze is omstreeks 1692 op Curaçao overleden.

C. Determeyer, die in 1687-1689 op Curaçao vertoefde (zie vroeger) behandelde daar de zaken der factorij tezamen met Beck, Pieter van Belle gaf op 8 Mei 1687, vóór het aanvaarden van de reis van Curaçao naar Spanje, aan Beck, in tegenwoordigheid van Jesaja Linkenberg, den secretaris van den Raad aldaar, discharge voor zijn - Beck's - onder het regime Barosso en Porcio gevoerde beheer (not. arch. 1475, no. 43). Volgens een acte voor notaris Van Bortel van 23 October 1691 (not. arch. 1477, no. 110) was het beheer der contanten op Curaçao onder de nieuwe administratie steeds bij Beck geweest en had Determeyer daar geen bemoeienis mede gehad.

In een nog niet te voren besproken acte van 9 October 1691 (not. arch. 1477 no. 104) verklaarde Josua van Belle, ten overstaan van notaris Van Bortel, dat hij indertijd gemachtigde in Nederland was geweest voor Balthazar Coymans - en van diens 
opvolgers - en dat hij, Josua, als zoodanig, doch ook als schuldeischer van het asiento, de op Curaçao gehouden boeken van het asiento had ontvangen en deze nog in zijn bezit had; eerst waren deze boeken gehouden door P. van Belle, later door Beck en Determeyer.

De factorijen in de West hadden steeds belangrijke uitgaven te doen; niet alleen moesten in een factorij als die op Curaçao de gelande slaven gevoed en onderhouden worden, totdat verdere verscheping mogelijk was, maar - en dit is zeer belangrijk de levering in Spaansch-Amerika ging meest op crediet (not. arch. 1475, no. 61).

Beck had tot 1 Mei 1685 van het oude asiento te goed 63.400 pesos en hierbij moest nog gevoegd worden een vordering op het nieuwe van ruim 5000 pesos, tot eind Mei 1687, toen P. van Belle van Curaçao vertrok (not. arch. 1477, no. 67). Determeyer werd op 9 October 1691 geacht een kleine 13000 pesos te goed te hebben (not. arch. 1477, no. 104); deze laatste had op Curaçao niet eens ten volle het salaris à 2500 pesos per jaar ontvangen, dat hij bij contract ten overstaan van notaris P. de Wit te Amsterdam van 1 Januari 1687 bedongen had. Verder had hij een klein bedrag te vorderen wegens zijn aandeel in de vracht van een door den oud-directeur Jan Doncker aan het asiento verhuurd vaartuig - de Nuestra Señora de las Nieves - en meerdere bedragen als aandeel in de premie van assurantie, wegens door hem Determeyer - geloopen risico op schepen, die van Curaçao met slaven naar andere havens in de buurt werden bevracht.

Uit verschillende der bestudeerde bescheiden blijkt ook nog welke kosten er verbonden waren aan de slaventransporten, welke credieten gegeven werden en hoe groot de transporten waren. Zoo moesten voor het reeds eenmaal genoemde schip St. Jago de Victoria (Kapitein Thomas Daniels, voor wien als gemachtigde in Nederland optrad zijn echtgenoote Johanna Cupius) rechten aan den Koning worden betaald over \pm 441 ton, à $112^{1} / 2$ pesos, dus bijna 50.000 pesos (not. arch. 1475, no. 37), terwijl aan vracht voor dit schip verschuldigd was 2200 pesos per maand (not. arch. 1475 , no. 38). In het begin van 1686 waren van Curaçao de meeste daar aanwezige slaven van de oude admistratie (Barosso en Porcio) door de factorij der nieuwe (Coymans) verscheept en de inkoopprijs was, uit de retouren, aan de respectievelijke directeuren der Compagnie (Kerckring volgde in 1686 Jan van Erpecum op) betaald. Op 7 Juni 1686 was men door den ouden voor- 
raad heen en men begon toen met van den directeur te ontvangen 407 koppen uit Angola, ex Sint Jan, kapitein Hubert Jansz, 358 ex Wapen van Zierikzee, kapitein Joost Bankert, enz., zoodat men op 8 Maart 1688 in totaal 4489 koppen van de Compagnie had overgenomen; op 19 Maart d.a.v. waren van deze 4489 nog 1075 slaven onverscheept aanwezig, waarop Kerckring beslag legde (zie vroeger) en waarvan hij het grootste deel met de St. Jago de Victoria verzond (not. arch. 1475, no. 61).

Op Curaçao werden alle slaven door de W. I. Compagnie aangevoerd en blijkbaar kreeg de directeur betaling uit hetgeen de slavenschepen mede terugbrachten, maar de factor ter plaatse van bestemming der slaven leverde op crediet (zie vroeger); de administratie zal dus wel altijd een saldo te goed gehad hebben van de koopers der slaven in Spaansch Amerika.

$\mathrm{Er}$ is nog sprake van een remise met het schip Koning Balthazar, kapitein Erasmus, van Francisco de Rivas, den factor te Panamá, welk geld bestemd was voor Beck en Determeyer, die een gemeenschappelijke rekening hadden, maar dat door Kerckring al mede in beslag werd genomen, verder van premie van assurantie op de schepen San Antonio, van Curaçao naar Havana en Vera Cruz en St. Pieter \& St. Paul, van Curaçao naar Caracas, alles tezamen 21.307 pesos, waarin Determeyer een aandeel had van $1 / 16$ (not. arch. 1477, no. 104). Voor de reis van $\mathrm{Cu}-$ raçao naar de bestemming der uitgevoerde slaven werden de schepen dus door ter plaatse gevormde combinaties verzekerd, in welke combinaties ook de leiders der factorij deelnamen.

De gewoonte, of de noodzakelijkheid, der 17e en 18e eeuw, om van alles en nog wat in beëedigde verklaringen voor de overheid, of in notarieele attestaties onder aanbod van eede, vast te leggen en de talrijke volmachten welke noodig waren in een tijd toen het verkeer nog weinig ontwikkeld was, stellen ons in staat het voorgeslacht - ook het koloniale voorgeslacht - in leven en bedrijf gade te slaan. De archiefstukken schenken niet altijd den lezer volkomen klaarheid in vaak zeer ingewikkelde transacties en de bijzonderheden zijn niet altijd meer van belang. Zich in de oude geschriften verdiepend echter en trachtend den inhoud te begrijpen, ziet men een brok verleden voor zich opleven.

Een Franschman, die in het begin der vorige eeuw een dik boek over Venezuela schreef, ${ }^{1}$ ) kende aan de Hollanders de eer toe van,

1) F. Depons, Voyage à la parte orientale de la Terre-Ferme, dans l'Amerique méridionale, Parijs 1806. 
door de stichting van een handelspost op Curaçao in 1634, de kolonisten op het tegenover dat eiland gelegen vasteland van Zuid-Amerika er toe gebracht te hebben, zich ernstig op den landbouw toe te leggen, de producten waarvan men op de nieuw geopende markt tegen allerlei behoeften kon inruilen. Zonder de Hollanders te noemen constateerde een Venezolaansch geschiedschrijver, dat de producten des lands door vreemdelingen op de Europeesche markt geïntroduceerd moesten worden, omdat Spanje zich op Mexico en Peru concentreerde ${ }^{\mathbf{1}}$ ).

Inderdaad, de Spaansche koloniale politiek bepaalde zich hoofdzakelijk tot exploitatie en dan nog oppervlakte-exploitatie; tot veel meer dan het winnen van goud en zilver, ten bate der Koninklijke schatkist, was het moederland niet in staat. Ondanks het monopoliestelsel waren het vreemdelingen die, openlijk of clandestien, aan de Spaansche koloniën moesten verschaffen wat zij voor haar ontwikkeling noodig hadden, d.w.z. aanvoer van werkkrachten en Europeesche fabrikaten, markten voor de koloniale landbouwproducten en crediet; vooral dit laatste kon de Spaansche staat niet aanbieden, doch de kapitaalkrachtige Nederlanden konden dat zooveel te beter.

Het bedrijfskapitaal van den tropischen landbouw bestond destijds grootendeels in de slavenmacht, welke bij aanvoer of suppletie, zooals wij gelezen hebben, op crediet geleverd werd. De betaling kon pas over eenigen tijd geschieden, wanneer de producten van den slavenarbeid geoogst waren, welke producten dan in den vorm van "retouren" in handen der credietgevers kwamen.

Wanneer wij bedenken wat er bovendien noodig was om de eigen vastelandskoloniën (Suriname, Berbice, Demerary en Essequibo) tot ontwikkeling te brengen en welk aandeel het Nederlandsche crediet gehad heeft in den economischen opbouw van de Fransche, de Deensche en de Britsche Antillen, dan staan wij versteld van de financieele machtspositie der kleine Republiek, in het tweede deel der 17e en in de 18e eeuw, ook in de West.

Ook al kunnen wij de methoden en de opvattingen - commercieele en koloniaalpolitieke - van dien tijd, waarvan ook uit de in dit artikel besproken bescheiden het een en ander aan het licht komt, niet bewonderen.

Amsterdam, November 1934.

1) Rafael-María Baralt. Resúmen de la Historia de Venezuela. Parijs 1841 . 